\title{
UJI DAYA HAMBAT EKSTRAK Chaetoceros calcitrans TERHADAP BAKTERI Aeromonas salmonicida
}

\author{
Maftuch $^{a}$, Heny Suprastyani ${ }^{a}$, dan Febby Hadi Setyawan ${ }^{a}, *$ \\ aProgram Studi Budidaya Perairan Fakultas Perikanan dan Ilmu Kelautan, Universitas Brawijaya Malang \\ J1. Veteran No. 1 Malang, Indonesia \\ ${ }^{*}$ Corresponding author : febbyhadi4@gmail.com
}

\begin{abstract}
Abstrak
Dampak dari penggunaan antibiotik dapat menimbulkan masalah pada kegiatan budidaya seperti resistensi bakteri dan bersifat residu bagi tubuh konsumen. Oleh karena itu, salah satu alternatif yang dapat digunakan untuk menghambat atau membunuh bakteri dengan menggunakan plankton Chaetoceros calcitrans. Penelitian ini bertujuan untuk mengetahui pengaruh pemberian ekstrak C. calcitrans yang dapat menghambat atau membunuh bakteri dan mengetahui perlakuan dengan dosis terbaik dalam menghambat pertumbuhan bakteri $A$. salmonicida. Metode yang digunakan adalah metode eksperimental dengan Rancangan Acak Lengkap (RAL) yang terdiri dari 4 perlakuan, 3 ulangan dan 2 kontrol. Perlakuan A (0.3 ppm), perlakuan B (15.3 ppm), perlakuan C (30.3 ppm), perlakuan D (45.3 ppm), kontrol positif (chlorampenicol $5 \mathrm{ppm}$ ) dan kontrol negatif (tanpa diberi ekstrak). Hasil penelitian menunjukkan rata-rata diameter zona bening tertinggi terdapat pada perlakuan D dengan nilai $5.37 \mathrm{~mm}$ dan hasil zona bening terendah terdapat pada perlakuan A dengan nilai $2.89 \mathrm{~mm}$. Penambahan dosis perlakuan ekstrak C. calcitrans terhadap diamater zona hambat menunjukkan pola linier dengan persamaan $\mathrm{y}=3.2067+0.0509 \mathrm{x}$ dan koefisien $\mathrm{R}^{2}=0.9262$. Hubungan antara pemberian ekstrak C. calcitrans dalam menghambat pertumbuhan bakteri A.salmonicida dengan rata-rata diamater zona hambat yang dihasilkan menunjukkan respon yang meningkat seiring dengan bertambahnya dosis ekstrak. Dari penelitian menunjukkan bahwa ekstrak C. calcitrans dapat menghambat pertumbuhan bakteri dan dosis dengan hasil tertinggi terdapat pada perlakuan D dengan dosis $45.3 \mathrm{ppm}$.
\end{abstract}

\begin{abstract}
The impact of use antibiotic can cause problems on aquaculture such as bacterial resistance and residues for consumer. Therefore, one of alternatives that can be used to inhibit or kill bacteria, one of which is the use of plankton Chaetoceros calcitrans. This research aims to know the influence of the granting C. calcitrans extract that can inhibit or kill bacteria and know the best dose for inhibit A. salmonicida bacteria. The experiment method used randomize completely design consist of four treatment and two control. A treatment $(0.3 \mathrm{ppm}), \mathrm{B}$ treatment $(15.3 \mathrm{ppm}), \mathrm{C}$ treatment $(30.3 \mathrm{ppm}), \mathrm{D}$ treatment $(45.3 \mathrm{ppm})$, positive control (add chlorampenicol 5ppm) and negative control (without extract). The result of research showed the highest average of clear zone diameter in D treatment $5.37 \mathrm{~mm}$ and the lowest average of clear zone diameter in A treatment $2.89 \mathrm{~mm}$, with linear equation $\mathrm{y}=3.2067+0.0509 \mathrm{x}$ and coefficients $\mathrm{R}^{2}=0.9262$. The relationship between $C$. calcitrans extract in inhibitng grwoth of $A$. salmonicida bacteria showed that the average diameter of the clear zone has increase in line with the addition of extracts. Form the research showed that the extract of $C$. calcitrans can be inhibit for bacteria growth and best obtained at the treatment dosage of D with a dose of $45.3 \mathrm{ppm}$.
\end{abstract}

Keywords: Aeromonas salmonicida, Chaetoceros calcitrans, Uji daya hambat

\section{PENDAHULUAN}

Kegiatan budidaya merupakan salah satu subsektor perikanan yang sangat berpotensial dalam masyarakat. Menurut [1], kegiatan budidaya perikanan berpotensi dalam meningkatan pendapatan masyarakat, memperluas kesempatan kerja dan kesempatan berusaha serta penghasil devisa Negara.

Salah satu faktor yang menghambat keberhasilan budidaya perairan adalah terjadinya serangan penyakit terhadap organisme budidaya. [2] menyatakan bahwa 
masalah penyakit merupakan kendala utama karena dapat merugikan usaha budidaya seperti penurunan produksi, penurunan kualitas air dan bahkan kematian total. Penyakit dapat disebabkan oleh beberapa jenis patogen seperti, virus, parasit, jamur dan bakteri

Salah satu wabah penyakit bakteri disebabkan oleh genus Aeromonas. Salah satu bakteri yang menginfeksi ikan dari genus Aeromonas adalah $A$. salmonicida. Menurut [3], A. salmonicida merupakan salah satu penyakit ikan golongan bakteri yang termasuk dalam kategori hama dan penyakit ikan karantina (HPIK). Menurut [4] jenis bakteri yang perlu penanggulangan serius adalah $A$. salmonicida. Bakteri tersebut dapat mengakibatkan furunkulosis atau ulcer yang menyebabkan kematian pada ikan budidaya.

Selama ini pencegahan terhadap serangan bakteri pada umumnya dilakukan dengan pemberian antibiotik dan bahan kimia. Akan tetapi, penggunaan antibiotik ternyata dapat menimbulkan efek samping bagi patogen itu sendiri maupun terhadap ikan yang dipelihara. Pemberian antibiotik secara terus menerus dapat menyebabkan organisme patogen menjadi resisten, sehingga penggunaan antimikroba menjadi tidak efektif [5]. Salah satu alternatif yaitu menggunakan bahan alami yang dapat digunakan untuk menghambat pertumbuhan bakteri A.salmonicida adalah ekstrak plankton $C$. calcitrans. Menurut [6], bahwa salah satu alternatif penggunaan antibiotik yaitu menggunakan dimana plankton $C$. calcitrans ini dapat mengobati penyakit ikan maupun udang karena mengandung senyawa terpenoid.

Penelitian ini dilakukan untuk mengetahui pengaruh pemberian ekstrak $C$. calcitrans terhadap daya hambat bakteri $A$. salmocida dan dosis terbaik ekstrak untuk menghambat pertumbuhan bakteri. Sehingga diharapkan mampu memberikan informasi yang berguna untuk kemajuan dunia perikanan yang ramah lingkungan.

\section{MATERI DAN METODE}

Penelitian ini dilaksanakan di Laboratorium Budidaya Ikan divisi Penyakit dan Kesehatan Ikan, Fakultas Perikanan dan Ilmu Kelautan, Universitas Brawijaya Malang, Laboratorium Sentra Ilmu Hayati (LSIH), Universitas Brawijaya Malang, dan Laboratorium Farmakologi, Fakultas Kedokteran, Universitas Brawijaya Malang.

Metode penelitian yang digunakan adalah metode eksperimen dengan rancangan penelitian yang digunakan adalah Rancangan Acak Lengkap (RAL). Penelitian terdiri dari 4 perlakuan dan 2 kontrol dengan masingmasing 3 kali ulangan. Perlakuan yang digunakan adalah pemberian ekstrak $C$. caclitrans dengan dosis yang berbeda sebagai daya hambat terhadap bakteri A. salmonicida . Perlakuan A (dosis $0.3 \mathrm{ppm}$ ), perlakuan B (dosis $15.3 \mathrm{ppm}$ ), perlakuan $\mathrm{C}$ (dosis 30.3 ppm) dan perlakuan D (dosis 45.3 ppm). Selain itu, pada perlakuan kontrol positif yaitu dengan penambahan antibiotik chlorampenicol 5 ppm, dan kontrol negatif (tanpa penambahan ekstrak).

Alat yang digunakan dalam penelitian adalah autoklaf, beakerglass, botol film, botol kaca, bunsen, cawan petri, colony counter, erlenmeyer, gelas ukur, hot plate, inkubator, jangka sorong, jarum ose, LAF, lemari pendingin, mikropipet, nampan, oven, pinset, pipet volume, rak tabung, evaporator, sonikasi, spatula, spektrofotometer, spidol marker, sprayer, tabung reaksi, timbangan analitik, timbangan digital, vortex dan washing bottle.

Bahan yang digunakan dalam penelitian adalah alkohol, alumunium foil, aquadest, blue tip, yellow tip, chlorampenicol, Ekstrak C. calcitrans, etanol 96\%, Isolat bakteri $A$. salmonicida, kapas, karet, kertas cakram, kertas label, $\mathrm{NaCl}$, warp, spirtus, tisu, TSA dan TSB.

\section{Pembuatan Eks trak C. Calcitrans}

Tahapan dari ekstraksi diawali dengan proses sonikasi, maserasi dan evaporasi. Pengadaan bahan ekstrak berupa plankton $C$. calcitrans yang didapatkan dari BPBAP 
(Balai Besar Budidaya Air Payau) Situbondo, dalam bentuk serbuk (powder). Kemudian dilakukan penimbangan serbuk plankton dan direndam dengan etanol $96 \%$ dengan perbandingan 1:6. Lalu, dilakukan sonikasi menggunakan sonikator selama 15 menit dengan amplitudo 70\%. Setelah itu, dilakukan maserasi selama $3 \times 24$ jam dan kemudian dilakukan penyaringan dengan kain saring dan dipekatkan menggunakan vacum rotary evaporator dengan suhu $60^{\circ} \mathrm{C}$ sampai mendapatkan hasil ekstrak berupa pasta, lalu hasil ekstrak ditimbang.

\section{Pembuatan Me dia Uji Agar Miring}

Media TSA (Tryptic Soy Agar) ditimbang $0.37 \mathrm{~g}$ dengan menggunakan timbangan digital. Media dimasukkan ke dalam erlenmeyer, kemudian dilarutkan dengan aquades sebanyak $10 \mathrm{ml}$ dan dihomogenkan. Media yang sudah homogen dimasukkan kedalam 2 tabung reaksi masingmasing sebanyak $5 \mathrm{ml}$. Tabung reaksi ditutup kapas dan dibungkus alumunium foil serta diikat dengan tali. Media disterilisasi dengan autoklaf pada suhu $121^{\circ} \mathrm{C}$ selama 15 menit dengan tekanan $1 \mathrm{~atm}$. Tabung reaksi yang berisi media steril dimiringkan dengan kemiringan $30^{\circ}$ dan ditunggu hingga padat. Kemudian dilakukan strike dalam keadaan steril.

\section{Kultur Bakteri}

Media TSB (Tryptic Soy Broth) ditimbang $0.6 \mathrm{~g}$ dengan menggunakan timbangan digital dan dimasukkan kedalam erlenmeyer. Media dilarutkan dengan aquades $20 \mathrm{ml}$ lalu dihomogenkan. Media yang sudah homogen ditutup kapas dan ditutup dengan aluminium foil kemudian diikat dengan tali, media disterilisasi dengan autoclaf pada suhu $121^{\circ} \mathrm{C}$ selama 15 menit dengan tekanan $1 \mathrm{~atm}$.

\section{Uji MIC (Minimum Inhibition Concentration)}

Media TSB ditimbang $1.5 \mathrm{~g}$ dengan menggunakan timbangan digital dan dimasukkan kedalam erlenmeyer. Media dilarutkan dengan aquades $50 \mathrm{ml}$ dan dihomogenkan. Setelah homogen, larutan dituang kedalam 10 tabung reaksi masingmasing sebanyak $5 \mathrm{ml}$. Masing-masing tabung reaksi kemudian ditutup kapas dan ditutup dengan aluminium foil kemudian diikat dengan tali, kemudian media disterilisasi dengan autoklaf pada suhu $121{ }^{\circ} \mathrm{C}$ selama 15 menit dengan tekanan $1 \mathrm{~atm}$.

\section{Uji Cakram}

Media TSA ditimbang 13.32 dengan menggunakan timbangan digital. Media dimasukkan kedalam erlenmeyer, kemudian dilarutkan dengan aquades sebanyak $300 \mathrm{ml}$ dan dihomogenkan. Erlenmeyer ditutup kapas dan dibungkus alumunium foil serta diikat dengan tali. Media disterilisasi dengan autoklaf pada suhu $121{ }^{\circ} \mathrm{C}$ selama 15 menit dengan tekanan 1 atm. Media dituang kedalam 18 cawan petri dengan masingmasing cawan diisi $\pm 20 \mathrm{ml}$ yang dilakukan didalam LAF (Laminar Air Flow) untuk menghindari kontaminasi dari bakteri lain, ditunggu hingga memadat.

\section{Peremajaan Bakteri}

Peremajaan bakteri dilakukan dalam keadaan steril, dengan menginokulasi kembali isolat bakteri $A$. salmonicida menggunakan jarum ose bulat yang telah dipanaskan diatas bunsen dan digores pada media agar miring secara zig-zag dalam kondisi yang steril kemudian diinkubasi pada suhu $32^{\circ} \mathrm{C}$ selama 24 jam.

\section{Kultur Bakteri}

Prosedur dalam kultur bakteri yaitu biakan bakteri yang sudah diremajakan pada media agar miring diambil dengan menggunakan jarum ose sebanyak 1 gores dalam keadaan steril. Kemudian ose yang berisi bakteri dicelupkan pada media yang sudah di persiapkan. Media disimpan pada inkubator dengan suhu $32^{\circ} \mathrm{C}$ selama 24 jam. 


\section{Memperoleh Kepadatan Bakteri $10^{7}$}

Bakteri A. salmonicida diperoleh dari Badan Karantina Ikan, Pengendalian Mutu dan Keamanan Hasil Perikanan (BKIPM) Kelas I Juanda Surabaya dengan kepadatan awal yang telah dihitung sebesar $4.48 \times 10^{13}$ CFU. Untuk mendapatkan bakteri dengan kepadatan $10^{7} \mathrm{sel} / \mathrm{ml}$, yaitu dipersiapkan NaFis berisi 9 ml pada tabung reaksi yang berjumlah 7 tabung dan dilakukan pengenceran bertingkat. Pada tabung pertama ditambahkan $1 \mathrm{ml}$ bakteri dari kepadatan $10^{13}$ CFU sehingga diperoleh kepadatan $10^{12}$, selanjutnya tabung kedua ditambahkan $1 \mathrm{ml}$ bakteri dari tabung pertama sehingga diperoleh kepadatan $10^{11}$ dan diteruskan hingga didapatkan bakteri dengan kepadatan $10^{7} \mathrm{CFU}$.

\section{Uji Aktvitas Antibakteri \\ Uji MIC (Minimum Inhibition Concentration)}

MIC dapat dilakukan dengan menggunakan TSB steril yang dimasukkan dalam tabung reaksi sebanyak $5 \mathrm{ml}$. Kemudian ekstrak plankton $C$. calcitrans ditambahkan pada tabung reaksi yang berisi TSB dengan dosis yang berbeda pada setiap tabungnya. Dosis yang digunakan pada uji MIC ini berdasarkan uji deret ukur (penelitian pendahuluan) yang dilakukan terlebih dahulu untuk penentuan dosis awal, dari hasil uji tersebut akan dibuat range lebih kecil untuk dilakukan uji MIC. Dalam uji MIC ini menggunakan kontrol positif yang diberi antibakteri sintetis (Chlorampenicol) $5 \mathrm{ppm}$ dan kontrol negatif tanpa pemberian ekstrak. Kemudian setiap tabung reaksi diberi isolat bakteri $100 \mu$, lalu diinkubasi dengan suhu $32^{\circ} \mathrm{C}$ selama 24 jam. Media dicek kekeruhannya menggunakan spektrofotometer dengan panjang gelombang $570 \mathrm{~nm}$ dan nilai absorbansi yang tertera pada monitor spektrofotometer dicatat. Uji MIC juga didasarkan pada indikator kekeruhan pada media TSB yang telah ditanam bakteri beserta eksrak dengan dosis yang berbeda dan diinkubasi selama 24 jam. Dosis uji MIC didasarkan pada tabung yang bening pertama kali dan absorbansi mendekati kontrol positif.

\section{Uji Cakram}

Cawan petri yang telah terdapat media TSA disiapkan terlebih dahulu. Kertas cakram steril direndam dengan larutan $C$. calcitrans dengan dosis yang berbeda. Perlakuan dosis berdasarkan dari Uji MIC yang dilakukan terlebih dahulu dan mendapatkan dosis yang sesuai untuk perlakuan. Adapun dosis yang digunakan adalah 0.3 ppm, 15.3 ppm, 30.3 ppm dan 45.3 ppm. Bakteri diambil sebanyak $0.1 \mathrm{ml}$ dengan menggunakan mikropipet dengan kepadatan yang ditentukan dan disebar pada seluruh permukaan TSA dengan menggunakan triangle. Setelah 10-15 menit kertas cakram yang direndam, diambil dengan hati-hati diletakkan pada media agar bagian tengah. Kemudian media yang telah ditanam bakteri dan diberi kertas cakram diinkubasi pada suhu $32^{\circ} \mathrm{C}$ selama $18-24$ jam. Media diamati dengan cara megukur diameter zona bening yang terbentuk disekitar kertas cakram dengan menggunakan jangka sorong.

\section{Paramater Uji}

Parameter uji dalam penelitian adalah hasil pengamatan yaitu hasil zona bening yang terlihat di sekitar kertas cakram yang sudah ditumbuhi oleh bakteri $A$. salmonicida.

\section{Analisis Data}

Data yang diperoleh kemudian dilakukan analisis secara statistik dengan menggunakan analisis keragaman atau uji F (ANAVA). Uji ini dilakukan untuk mengetahui pengaruh perlakuan (variabel bebas) terhadap respon zona hambat (zona bening) yang diukur atau uji $F$. Apabila nilai uji $F$ berbeda nyata atau berbeda sangat nyata maka dilanjutkan dengan uji BNT (Beda Nyata Terkecil) yaitu untuk mengetahui perbedaan antar perlakuan. Kemudian untuk mengetahui hubungan antar perlakuan dengan diameter zona hambat (zona bening) digunakan uji polynomial orthogonal 
yang memberikan keterangan mengenai pengaruh keterangan terbaik.

\section{HASIL DAN PEMBAHASAN}

\section{Uji MIC \\ (Minimum \\ Inhibition \\ Concentration)}

Uji MIC (Minimum Inhibition

Concentration) merupakan uji yang dilakukan untk mengetahui dosis terkecil dalam menghambat pertumbuhan bakteri, yang dapat dilihat dari absorbansi dan perubahwan warna yang terjadi pada media.

Hasil pengamatan uji MIC yang dilakukan menggunakan berbagai macam dosis dari ekstrak C. calcitrans disajikan pada Tabel 1.

Tabel 1. Hasil Pengamatan Uji MIC

\begin{tabular}{|c|c|c|c|}
\hline No. & $\begin{array}{l}\text { Kons entrasi } \\
\text { (ppm) }\end{array}$ & $\begin{array}{l}\text { Absorbans } \\
\text { i }\end{array}$ & Warna \\
\hline 1 & 0.03 & 0.4412 & Keruh \\
\hline 2 & 0.05 & 0.3633 & Keruh \\
\hline 3 & 0.07 & 0.3550 & Keruh \\
\hline 4 & 0.09 & 0.3422 & Keruh \\
\hline 5 & 0.11 & 0.2675 & $\begin{array}{l}\text { Agak } \\
\text { bening }\end{array}$ \\
\hline 6 & 0.3 & 0.2654 & Bening \\
\hline 7 & 0.5 & 0.2632 & Bening \\
\hline 8 & $(+)^{\text {Kontrol }}$ & 0.2650 & Bening \\
\hline 9 & $(-)$ Kontrol & 1.0690 & Keruh \\
\hline
\end{tabular}

Keterangan:

Kontrol (+) : Chlorampenicol 5 ppm

Kontrol (-) : tanpa pemberian ekstrak

Hasil diatas menunjukkan bahwa dosis 0.3 ppm dapat menghambat bakteri $A$. salmonicida, dikarenakan dosis tersebut mendekati nilai kontrol positif. Dipilihnya dosis 0.3 ppm merupakan dosis yang efisien digunakan sebagai dosis MIC. Menurut [7], Chaetoceros merupakan pakan alami yang dapat menghambat pertumbuhan beberapa bakteri patogen.

Pengamatan MIC tidak hanya dilakukan dengan menggunakan indikator absorbansi tapi juga dapat dilihat dari perubahan warna yang terjadi. Menurut [8], spektrofotometer tidak mampu membedakan kekeruhan warna ekstrak dengan kekeruhan bakteri oleh karena itu pengamatan bisa dibantu dengan melihat warna dan membandingkan dengan kontrol (Gambar 1).

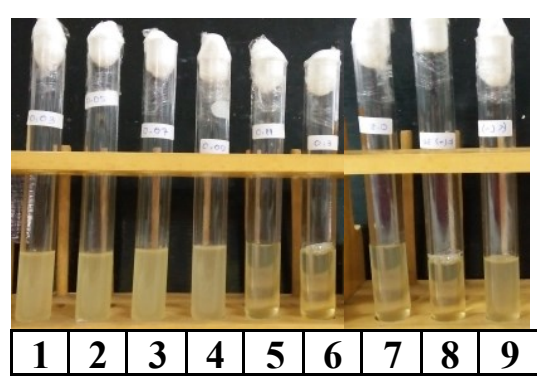

Gambar 1. Hasil Uji MIC

Hasil uji MIC dengan melihat pada perubahan kondisi warna menunjukkan bahwa dapat dilihat pada tabung ke-6 (dengan dosis $0.3 \mathrm{ppm}$ terdapat) terdapat perubahan warna media yang mendekati warna pada kontrol positif, sehingga dapat disimpulkan bahwa tabung ke-6 merupakan dosis MIC. Hasil tersebut dikarenakan ekstrak C. calcitrans memiliki senyawa antibakteri, sehingga mampu menghambat pertumbuhan bakteri $A$. salmonicida dan mengakibatkan media dalam tabung menjadi bening. Menurut [9], $C$. calcitrans memiliki senyawa antibakteri berupa senyawa terpenoid yang dapat menghambat pertumbuhan bakteri.

\section{Uji Cakram}

Uji cakram dilakukan dengan menggunakan perlakuan dosis $0.3 \mathrm{ppm}, 15.3$ ppm, 30.3 ppm dan 45.3 ppm serta kontrol. positif dan negatif. Digunakan dosis tersebut berdasarkan dari hasil uji MIC, dimana dengan dosis $0.3 \mathrm{ppm}$ telah dapat menghambat pertumbuhan bakteri $A$. salmonicida.

Metode uji daya hambat ini sesuai dengan [10] yaitu menggunakan media yang berbeda dalam setiap perlakuan dosis. Hasil uji daya hambat disajikan pada Gambar 2.

Hasil uji cakram dari ekstrak C. calcitrans dengan empat perlakuan dosis dan tiga kali ulangan yang dilakukan, didapatkan diamater zona bening setelah dilakukan 
pengamatan selama 24 jam seperti yang disajikan pada Tabel 2.

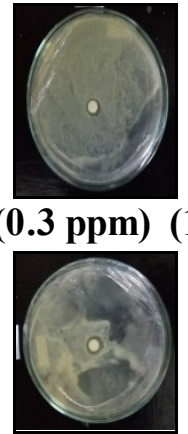

(45.3 ppm)

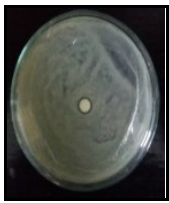

(15.3 ppm) (30.3 ppm)

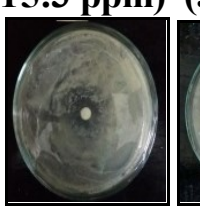

$(\mathbf{K}+)$
Gambar 2. Hasil Uji Cakram

Tabel 2. Hasil Rata-Rata Zona Hambat Bakteri

\begin{tabular}{cc}
\hline $\begin{array}{c}\text { Konsentrasi ekstrak } \\
(\mathbf{p p m})\end{array}$ & $\begin{array}{c}\text { Rata-rata diame ter } \\
\text { zona hambat }(\mathbf{m m})\end{array}$ \\
\hline 0.3 & $8.89^{\mathrm{a}}$ \\
15.3 & $10.51^{\mathrm{b}}$ \\
30.3 & $10.70^{\mathrm{bc}}$ \\
45.3 & $11.37^{\mathrm{d}}$ \\
Kontrol (-) & 0 \\
Kontrol (+) & 16.05 \\
\hline
\end{tabular}

Keterangan:

Kontrol (+) : Chlorampenicol 5 ppm

Kontrol (-) : tanpa pemberian ekstrak

Berdasarkan Analisis Varian (Anava), perlakuan pemberian ektrsak $C$. calcitrans memberikan pengaruh sangat nyata terhadap diameter zona hambat pertumbuhan bakteri A.salmonicida. Hasil rata-rata diameter zona hambat yang didapat, pada kontrol $(+)$ mendapatkan hasil rata-rata zona $b$ sebesar $16.05 \mathrm{~mm}$ dan kontrol (-) mendapatkan hasil rata-rata sebesar $0 \mathrm{~mm}$, sedangkan hasil pada perlakuan tertinggi terdapat pada perlakuan D dengan dosis $45.3 \mathrm{ppm}$ yaitu sebesar 11.37 $\mathrm{mm}$, sedangkan nilai rata-rata diameter zona bening terendah terdapat pada perlakuan $\mathrm{A}$ dengan dosis $0.3 \mathrm{ppm}$ yaitu sebesar $8.89 \mathrm{~mm}$.

Hubungan antara konsentrasi ekstrak $C$. calcitrans dan zona hambat yang diperoleh dari hasil analisis regresi disajikan berupa grafik yang dapat dilihat pada Gambar 3 .

Berdasarkan Gambar 3, terlihat hubungan antara penambahan dosis perlakuan ekstrak C. calcitrans terhadap diameter zona hambat menunjukkan pola linier dengan persamaan $\mathrm{y}=9.2067+0.0509 \mathrm{x}$ dan koefisien $\mathrm{R}^{2}=0.9262$ serta koefisien korelasi (r) sebesar 0.90 . Terlihat adanya keeratan hubungan (korelasi) antara konsentrasi ekstrak dan zona hambat pertumbuhan bakteri $A$. salmonicida yang menunjukkan korelasi positif antara 2 variabel tersebut. Artinya, semakin besar konestrasi ekstrak $C$. Calcitrans yang ditambahkan maka semakin lebar diameter zona hambat yang terbentuk.

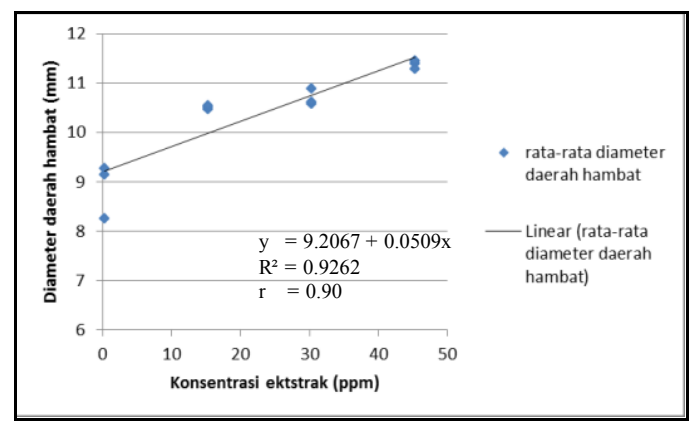

Gambar 3. Grafik Hubungan Zona Hambat

Uji MIC (Minimum Inhibition Concentration) dan uji cakram yang telah dilakukan menunjukkan bahwa ekstrak dari $C$. calcitrans mampu menghambat pertumbuhan bakteri A. salmonicida hal tersebut dapat dilihat dari zona hambat yang terbentuk. Bahan aktif juga sangat berperan penting dalam menghambat pertumbuhan bakteri A.salmonicida. Bahan aktif yang terkandung dalam ekstrak C.calcitrans adalah senyawa terpenoid.

Menurut [11], terpenoid merupakan turunan-turunan terpena atau senyawasenyawa yang strukturnya mirip terpenda. Molekul terpenoid dapat mengandung gugus karboksi, hidroksi, formil atau gugus yang lain. Menurut [12], salah satu komponen dari alga yang tergolong dalam senyawa terpendoid adalah diterpene-benzoate bromophycolides, dimana senyawa tersebut dapat menghambat pertumbuhan bakteri.

Menurut [13], mekanisme antibakteri senyawa terpenoid adalah merusak struktur dinding sel dan mengganggu kerja transpor aktif dan kekuatan ion didalam membran sitoplasma bakteri. Menurut [14], senyawa antibakteri mengakibatkan terjadi interaksi dengan dinding sel mikroorganisme akan 
terjadi denaturasi protein dan meningkatkan permeabilitas mikroorganisme. Interaksi antar mikroorganisme mengakibatkan perubahan keseimbangan muatan dalam molekul protein, sehingga terjadi perubahan struktur protein dan menyebabkan terjadinya koagulasi. Protein yang mengalami denaturasi dan koagulasi akan kehilangan aktivitas fisiologis sehingga tidak dapat berfungsi dengan baik. Perubahan struktur protein pada dinding sel bakteri akan meningkatkan permeabilitas sel sehingga pertumbuhan sel akan terhambat dan kemudian sel menjadi rusak. Selanjutnya senyawa tersebut akan mendenaturasi dan menginaktifkan protein seperti enzim sehingga mempengaruhi metabolisme sel. Menurut [15], senyawa terpenoid dapat menghambat pertumbuhan dengan mengganggu proses terbentuknya membran dan atau dinding sel, membran atau dinding sel tidak terbentuk atau terbentuk tidak sempurna.

\section{KESIMPULAN}

Ekstrak C. calcitrans dapat menghambat bakteri A. salmonicida dan hasil zona hambat tertinggi terdapat pada perlakuan $\mathrm{D}$ dengan dosis $45.3 \mathrm{ppm}$ dengan nilai rata-rata zona hambat sebesar 5.37.

\section{REFERENSI}

[1] Pontoh, O. 2012. Analisa usaha budidaya ikan dalam jaring apung di Desa Tandengan Kecamatan Eris Kabupaten Minahasa, Sulawesi Utara. Pacific Journal. 2(7): 1424-1428.

[2] Ashari, C., R. A. Tumbol dan M. E. F. Kolopita. 2014. Diagnosa penyakit bakterial pada Ikan Nila (Oreocrhomis niloticus) yang di budidaya pada jaring tancap di Danau Tondano. Budidaya Perairan. 2(3):24-30.

[3] Muqsith, A. 2013. Aktivitas antibakteri ekstrak fenol Gracillaria verrucosa terhadap bakteri Aeromonas salmonicida secara in vitro. Samkia.3(1): 69-75.
[4] Sumino, A. Supriyadi dan Wardiyanto. 2013. Efektivitas ekstrak daun ketapang (Terminalia cattapa L.) untuk pengobatan infeksi Aeromonas salmonicida pada ikan patin (Pangasioniodon hypophthalmus). Jurnal Sain Veteriner. 3(1): 79-88.

[5] Rinawati, N. D. 2011. Daya antibakteri Tumbuhan Majapahit (Crescentia cujete L.) terhadap bakteri Vibrio alginolyticus . Fak. Matematika dan Ilmu Pengetahuan Alam. ITS Surabaya. 1-13.

[6] Seraspe, E. B., S. Gabotero, M. R. De la Peña, I. G. Pahila and E.C. Amar. 2014. Evaluation of dietary freeze-dried Chaetoceros calcitrans supplementation to control Vibrio harveyi infection on Penaeus monodon juvenile. Aquaculture 432. 212-216.

[7] Setyaningsih, I ,, L. Hardjito, D. R. Monintja, M. F. A. Sondita, M. Bintang, N. Lailati dan L. Panggabean. 2017. Ekstraksi senyawa antibakteri dari diatom Chaetoceros calcitrans dengan berbagai metode. Jurnal Biologi Indonesia. 5(1): 23-33.

[8] Putri, R. W., W, Tjajaningsih dan D, Handijatno. 2008. Daya antibakteri pigmen pyocyanin dari isolate Pseudomonas aeruginosa terhadap Aeromonas hydrophila secara in vitro. Jurnal berkala ilmiah perikanan. 3(1): 65-73.

[9] Seraspe, E. B., B. F. Ticar, M. J. Formacion, I. G. Pahila, M. R. de la Pena and E. C. Amar. 2012. Antibacterial properties of the microalgae Chaetoceros calcitrans. Asian Fisheries Science. 25: 343-356

[10] Ibrahim, A., Y. T. Adiputra, A. Setyawan dan S. Hudaidah. 2013. Potensi ekstrak kulit buah dan biji rambutan (Nephelium lappaceum) sebagai senyawa antibakteri patogen pada ikan. Jurnal 
Rekayasa dan Teknologi Budidaya Perairan. 1(2): 135-144

[11] Sumardjo, D. 2008. Pengantar Kimia : Buku Panduan Kuliah Mahasiswa Kedokteran dan Program Strata I Fakultas Bioeksakta. Jakarta. EGC. $650 \mathrm{hlm}$

[12] Shannon, E . and N. Abu-Ghannam. 2016. Antibacterial derivatives of marine algae: an overview of pharmacological mechanisms and applications. Marine drugs. 14(81): 1-23.

[13] Fadhilla, R., E. A. P. Iskandra dan H. D. Kusumaningrum. 2012. Aktivitas antibakteri ekstrak tumbuhan Rumput
Lumut Hati (Marchantia paleacea) terhadap bakteri patogen dan perusak pangan. J. Teknologi dan Industri Pangan. 23(2): 126-131.

[14] Agustin, D. W. 2005. Perbedaan khasiat antibakteri bahan irigasi antara hidrogen peroksida 3\% dan infusum daun Sirih $20 \%$ terhadap bakteri mix. Maj. Ked. Gigi. (Dent. J.). 38(1): 45-47

[15] Darsana, I. G. O., I. N. K. Besung dan H. Mahatmi. 2012. Potensi daun Binahong (Anredera cordifolia (tenore) Setenis) dalam menghambat pertumbuhan bakteri e.coli secara in vitro. Indonesia Medicus Veterinus. 1(3):337-351. 